"Buku ini mengulas secara komprehensif tentang manajemen pendidikan karena itu sangat penting dibaca oleh para pengelola, praktisi, dan pemerhati pendidikan"

Dr. Basman, M.Ag

(Kepala Biro Administrasi Umum, Akademik, dan Kemahasiswaan IAIN Sultan Amai Gorontalo)

"Buku ini sangat menarik. Berisi dari hulu ke hilir pada proses admnistrasi di lembaga pendidikan, khususnya sekolah. Apresiasi terbaik untuk hadirnya buku ini karena dapa menyumbangkan kontribusi dalam pengelolaan administrasi pendidikan. Wajib dibaca bagi civitas akademika dan masyarakat umum, bilkhusus untuk yang ingin mengembangkan keahlian keilmuannya di bidang administrasi pendidikan ataupun manajemen pendidikan"

$\sim$ Prof. Dr. Novianty Djafri, M.Pd.

(Guru Besar Manajemen Pendidikan, Dosen Universitas Negeri Gorontalo)

"Buku ini sangat dianjurkan untuk dibaca oleh mahasiswa maupun masyarakat umum yang ingin memiliki wawasan tentang administrasi di bidang pendidikan. Keunggulan buku ini adalah membahas secara mendalam berbagai seluk-beluk administrasi pendidikan"

Prof. Dr. Akhyak, M.Ag

(Direktur Program Pascasarjana LAIN Tulungagung)

"Buku yang menyajikan perspektif baru dalam memahami manajemen pendidikan, mencerahkan, dan perlu untuk dibaca"

Prof. Dr. Aan Hasanah, M.Ed

(Wakil Dekan I Fakultas Tarbiyah dan Keguruan UIN Sunan Gunung Djati Bandung)

"Buku ini wajib dimiliki oleh mahasiswa dalam menekuni bidang manajemen pendidikan, penulis dengan gaya bahasa yang mudah dipahami sehingga buku ini dapat dijadikan referensi bagi berbagai kalangan dalam mengkaji dan memahami manajemen pendidikan'

Dr. Herson Anwar, M.Pd

(Ketua Prodi S2 Manajemen Pendidikan Islam IAIN Sultan Amai Gorontalo)

"Buku Pokoknya Administrasi Pendidikan yang ada digenggaman anda ini adalah buku yang representatif hagi akademisi di bidang manajamen pendidikan maupun manajemen pendidikan islam, terlebih di dalamnya ada pembahasan mengenai kurikulum yang menjadi jantungnya pendidikan

Dr. Yuli Utanto, M.Si.

(Doktor Pengembangan Kurikukum, Dosen Universitas Negeri Semarang)

"Anda ingin sukses dalam mengelola suatu lembaga pendidikan? Temukan dalam buku ini!!" Drs. Suleman Tongkonoo, M.HI

(Kepala Kantor Kementerian Agama Kabupaten Bone Bolango)

ANGGOTAIKARINOMOR3121//11/2010

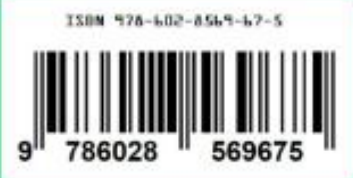

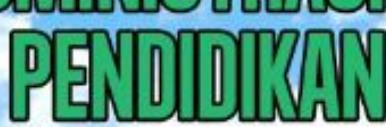

Habibie Yusuf, S.Pd.I, M.Pd

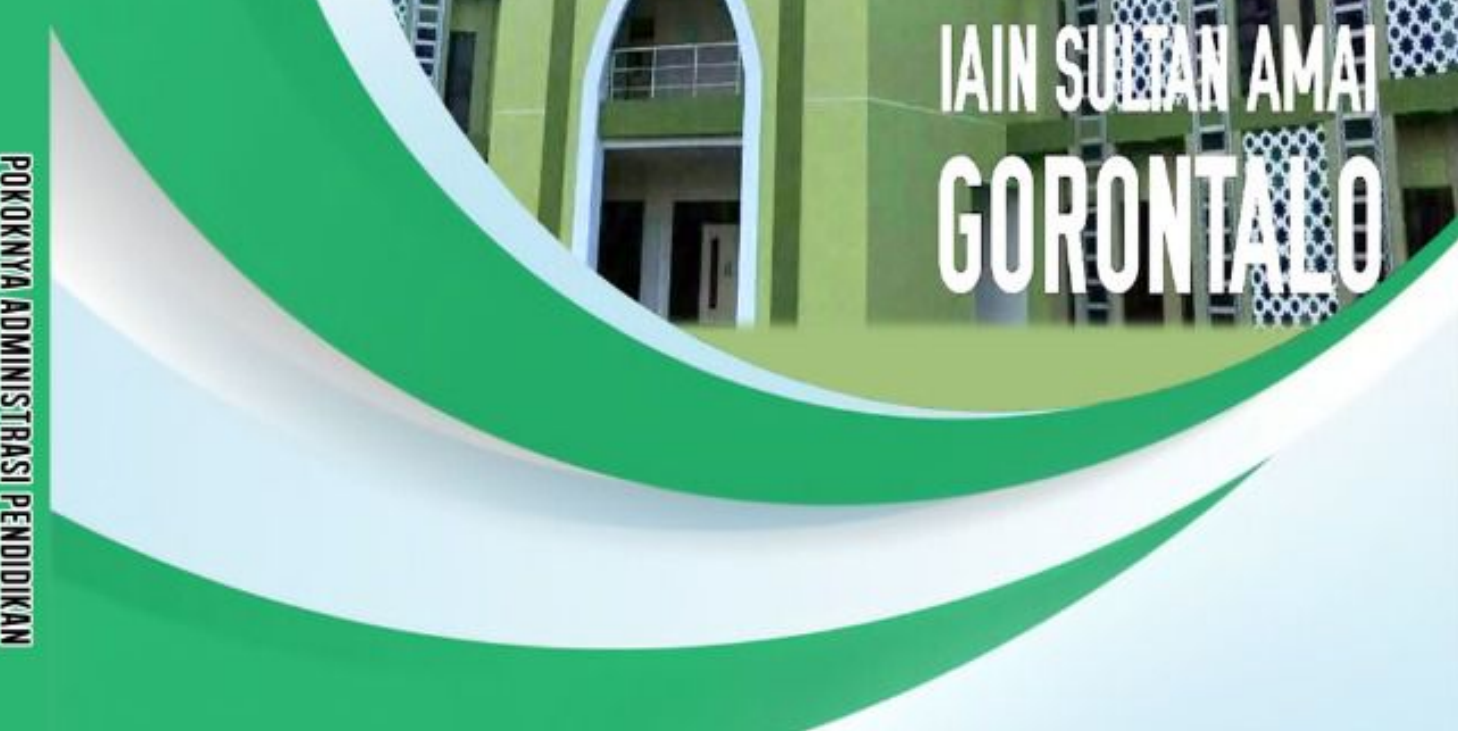

Pengantar:

Dr. Bahrissalim, MA

Direktur Madrasah Pembangunan

(Labschool UIN Jakarta)

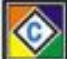

Penerbit Cahaya Abadi 


\title{
POKOKNYA ADMINISTRASI PENDIDIKAN
}

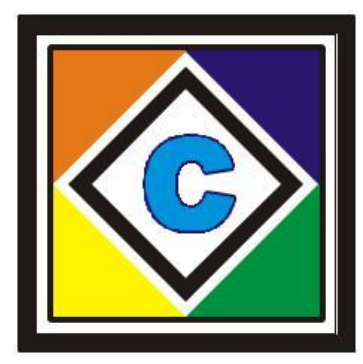

\author{
Oleh: \\ Habibie Yusuf, S.Pd.I, M.Pd
}

\section{PENERBIT CAHAYA ABADI TULUNGAGUNG 2019}




\section{POKOKNYA ADMINISTRASI PENDIDIKAN}

Oleh:

Habibie Yusuf, S.Pd.I, M.Pd

Hak Cipta Dilindungi Undang-Undang. Dilarang keras mengutip, menjiplak, memfotokopi sebagian atau seluruh isi buku ini serta memperjualbelikannya tanpa izin tertulis dari Penerbit CAHAYA ABADI.

Diterbitkan oleh:

Penerbit CAHAYA ABADI Tulungagung

Email: penerbitcahayaabadi@yahoo.co.id Telp. 085234635471

Editor: Ahmad Zaenuri, M.Pd.I

Habibie Yusuf

Pokoknya Administrasi Pendidikan / Habibie Yusuf : editor, Ahmad Zaenuri - Tulungagung : Cahaya Abadi, 2019

$147 \mathrm{hlm}$. ; $23 \mathrm{~cm}$.

ISBN: 978-602-8569-67-5

Cetakan 1, September 2019

ANGGOTA IKAPI NOMOR: 121/JTI/2010 


\section{PENGANTAR}

\section{Direktur Madrasah Pembangunan (Labschool UIN Jakarta)}

Tata kelola yang baik bidang administrasi suatu lembaga pendidikan dapat menjadikan lembaga tersebut menjadi lembaga pendidikan berkualitas. Karena pada intinya administrasi adalah kerja sama antar manusia karena manusia adalah makhluk yang lemah dan tidak sempurna, sementara pada sisi yang lain manusia mempunyai berbagai macam kebutuhan yang senantiasa menuntut untuk dipenuhi, maka manusia membutuhkan manusia lain untuk bekerja secara bersama-sama dalam memenuhi kebutuhannya. Dengan demikian, administrasi adalah semua kegiatan yang dilakukan secara bersama-sama untuk mewujudkan tujuan yang telah ditetapkan.

Sedangkan administrasi pendidikan merupakan proses atau upaya pencapaian suatu tujuan pendidikan dengan memperhatikan berbagai komponen pendidikan sehingga dapat melakukan perbaikan sistem pendidikan dengan memanfaatkan berbagai perangkat pendukung kegiatan proses pembelajaran yang meliputi perencanaan, pengorganisasian, pengarahan, pengkoordinasian, pengawasan, pembiayaan, dan pelaporan, dengan memanfaatkan fasilitas yang tersedia, baik personal, material, dan spiritual demi tercapainya tujuan pendidikan secara efektif dan efisien.

Untuk itu, pendidik dan tenaga kependidikan dituntut untuk memiliki pemahaman yang baik tentang konsep administrasi pendidikan dan memiliki ketrampilan praktis dalam mengelola proses pembelajaran dan administrasi 
sekolah, agar tujuan pendidikan yang telah ditetapkan dapat tercapai secara maksimal. Selain itu, kepala sekolah sebagai manajer lembaga pendidikan juga sangat menentukan kualitas atau keunggulan lembaga pendidikan selain pembelajaran yang dilakukan guru atau pendidik.

Buku "Pokoknya Administrasi Pendidikan" yang ada dihadapan pembaca ini adalah karya Habibie Yusuf, M.Pd. Dia adalah dosen Fakultas Ilmu Tarbiyah dan Keguruan IAIN Sultan Amai Gorontalo. Buku ini ditulis berdasarkan pengalamannya sebagi dosen yang mengampu Mata Kuliah Administrasi Pendidikan. Penulis memaparkan konsep dan ketrampilan praktis tentang administrasi pendidikan dan yang menarik pembaca khususnya tenaga kependidikan dikenalkan tentang kurikulum dan manajemen peserta didik, dengan harapan para tenaga kependidikan dapat memahami urgensi kurikulum dan manajemen peserta didik dalam mencapai tujuan pendidikan yang ada di sekolah atau madrasah selain ketatalaksanaan lembaga pendidikan. Persoalan Standar Nasional Pendidikan (SNP) dan penjamian mutu lembaga pendidikan juga melengkapi wawasan pembaca khususnya para mahasiswa, yang sejak kuliah harus memiliki wawasan tersebut dan memahami bagaimana memastikan lembaga pendidikan tetap berkualitas.

Kehadiran buku ini, menjadi sebuah momentum yang sangat strategis, karena hadir di saat tantangan teknologi dan ilmu pengetahuan yang begitu cepat dan menuntut lembaga pendidikan untuk memberikan layanan prima kepada peserta didik dan masyarakat belajar lainnya. Selain itu, berharap buku ini tidak saja menjadi sumber inspirasi 
untuk dijadikan rujukan dalam pengembangan lembaga pendidikan, tapi juga menjadi inspirasi untuk pengembangan tulisan-tulisan serupa sebagai perwujudan dari kreatifitas dan inovasi para praktisi pendidikan, para peneliti maupun akademisi pendidikan untuk melahirkan karya-karya serupa. Mudah-mudahan kehadiran buku ini bermanfaat bagi kemajuan pendidikan di Indonesia.

Jakarta, 17 September 2019

Dr. Bahrissalim, MA 


\section{PRAKATA}

\section{Penulis}

Administrasi Pendidikan merupakan usaha menciptakan kerja sama antara pendidik dan tenaga kependidikan untuk mengefektifkan seluruh proses kegiatan di sekolah, baik di dalam maupun di luar kelas. Dengan demikian, yang bertugas memegang administrasi pendidikan haruslah orang yang telah terlatih, terampil, dan handal dalam bidang administrasi pendidikan, serta telah mendapatkan ilmu dan pelatihan dalam waktu yang relatif tidak singkat. Administrasi pendidikan memiliki tujuan untuk mencapai apa yang menjadi tujuan dari pendidikan itu sendiri.

Dalam buku "Pokoknya Administrasi Pendidikan" hadir sebagai salah satu referensi bagi para pembaca, baik praktisi pendidikan, pembaca umum, mahasiswa, dan pemerhati dunia pendidikan. Pembahasan kurikulum sampai dengan pembahasan hubungan lembaga pendidikan dengan masyarakat dalam buku ini adalah bentuk upaya penulis dalam menyajikan pembahasan admnistrasi pendidikan secara komprehensif.

Judul buku "Pokoknya Administrasi Pendidikan" memiliki dua makna bagi penulis, yakni: 1. Bermaknya pokok-pokok yang ada di admnistrasi pendidikan, 2. Dapat pula bermakna Pokokoknya Harus Administrasi Pendidikan yang menganalogikan betapa pentingnya pembahasan administrasi di dunia pendidikan. Judul pada buku ini, diawali dengan kata "Pokoknya" yang terinspirasi dari 
mendiang Prof. Chaedar Alwasilah, Ph.D, MA satu dari sedikit dosen yang difavoritkan oleh penulis. Kata "Pokoknya" pun akan dijadikan judul awal di setiap buku yang penulis tulis, "Pokoknya Supervisi Akademik", "Pokoknya Supervisi Manajerial", dan "Pokoknya......." apapun dalam bidang manajemen pendidikan bisa lahir dalam karya-karya berikutnya. Semoga buku ini bermanfaat dan membawa keberkahan bagi para pembaca dan bagi penulis.

Gorontalo, 17 September 2019 Penulis, Habibie Yusuf, S.Pd.I, M.Pd 


\section{DAFTAR ISI}

Halaman

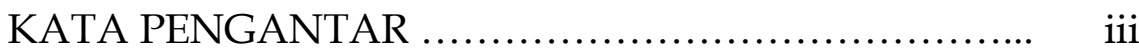

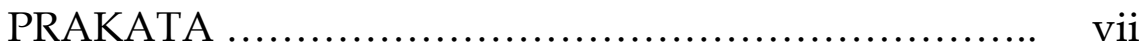

DAFTAR ISI ........................................... ix

BAB 1: Pengertian Manajemen Pendidikan ................ 1

A. Peran dan Fungsi Manajeman Pendidikan ............ 5

B. Ruang Lingkup Manajemen Pendidikan .............. 8

BAB 2: Pengertian dan Struktur Organisasi Lembaga

Pendidikan ................................................. 9

A. Jalur, Jenjang, dan Jenis Lembaga Pendidikan ........ 12

B. Kriteria Keberhasilan Lembaga Pendidikan ........... 17

BAB 3: Konsep Dasar Kurikulum ........................ 19

A. Pengertian Kurikulum ............................. 19

B. Fungsi Kurikulum .................................. 21

C. Peranan Kurikulum ................................ 22

D. Pengembangan Kurikulum ........................ 24

BAB 4: Konsep Dasar Manajeman Peserta Didik ........ 27

A. Pengertian Manajemen Peserta Didik ................ 27

B. Tujuan dan Fungsi Manajemen Peserta Didik ........ 28

C. Prinsip-Prinsip Manajemen Peserta Didik ............ 30

D. Pendekatan Manajemen Peserta Didik ............... 31

E. Pendataan Data Peserta Didik ......................... 32

F. Mutasi Peserta Didik (Pindah Sekolah) .............. 36

G. Layanan Khusus ..................................... 41

BAB 5: Pengertian dan Jenis-Jenis Tenaga

Kependidikan ......................................... 43

A. Pengangkatan dan Penempatan Tenaga

Kependidikan ....................................... 46

B. Pembinaan dan Pengembangan Tenaga

Kependidikan 
C. Pemberhentian Tenaga Kependidikan ................ 49

BAB 6: Pengertian dan Jenis-Jenis Fasilitas Pendidikan .. 51

A. Pengadaan Fasilitas Pendidikan ...................... 52

B. Pendayagunaan dan Pemeliharaan Fasilitas

Pendidikan ......................................... 54

C. Penghapusan Fasilitas Pendidikan .................... 55

D. Pelaporan Data Fasilitas Pendidikan ................. 56

BAB 7: Konsep Dasar Pembiayaan Pendidikan ........... 59

A. Prinsip Dasar Pembiayaan Pendidikan ................ 61

B. Perbedaan Pembiayaan Pendidikan dan Ekonomi

Pendidikan .......................................... 61

C. Fungsi Pembiayaan Pendidikan ...................... 64

D. Sumber-Sumber Pembiayaan Pendidikan ............. 64

E. Perencanaan Anggaran dan Belanja Lembaga

Pendidikan .......................................... 67

F. Pelaksanaan Anggaran Pendidikan ................... $\quad 70$

G. Pengawasan Pembiayaan Pendidikan ................ $\quad 73$

BAB 8: Konsep Dasar Hubungan Lembaga Pendidikan dengan Masyarakat ....................................... $\quad 75$

A. Jenis-Jenis Kegiatan Hubungan Lembaga

Pendidikan dengan Masyarakat ....................... 81

B. Bentuk-Bentuk Kerjasama Lembaga Pendidikan dengan Masyarakat .................................. 84

C. Peningkatan dan Pendayagunaan Partisipasi Masyarakat ......................................... 85

BAB 9: Konsep Dasar dan Fungsi Ketatalaksanaan Lembaga Pendidikan ......................................

A. Prosedur Penataan Ketatalaksanaan Lembaga Pendidikan ............................................ 90

B. Sistem Informasi Manajeman Lembaga Pendidikan . 93 BAB 10: Kebijakan Umum Pendidikan Nasional ......... 95 A. Struktur Tata Organisasi Pendidikan Nasional ....... 98 
B. Budaya Organisasi di Kemendikbud dan 5 Budaya Kerja Kemenag RI

BAB 11: Standar Nasional Pendidikan sebagai Acuan Mutu Pendidikan Nasional

A. Sistem Penjaminan Mutu Pendidikan (SPMP) sebagi Acuan Mutu Pendidikan Nasional

B. Sistem Penjaminan Mutu Internal (SPMI) dan Sistem Penjaminan Mutu Eksternal (SPME)

C. Pemetaan Mutu Pendidikan melalui Evaluasi Diri Sekolah (EDS)

BAB 12: Pelembagaan Penjaminan Mutu Pendidikan di Tingkat Pemerintah Pusat, Provinsi, dan

Kabupaten/Kota

BAB 13: Penyelenggara dan Masyarakat Pelembagaan Penjaminan Mutu Pendidikan pada Tingkat Satuan Pendidikan

DAFTAR PUSTAKA 


\section{BAB 1 \\ Pengertian Manajemen \\ Pendidikan}

Menurut asal katanya, Management berasal dari kata latin yaitu "manus" yang artinya "to control by hand" atau "gain result". Kata manajemen juga berasal dari bahasa Italia maneggiare yang berarti "mengendalikan," Kata ini mendapat pengaruh dari bahasa Perancis manège yang berarti "kepemilikan kuda" (yang berasal dari Bahasa Inggris yang berarti seni mengendalikan kuda), dimana istilah Inggris ini juga berasal dari bahasa Italia, yang memiliki arti seni melaksanakan dan mengatur.

Manajemen dapat didefinisikan sebagai "proses perencanaan, pengorganisasian, pengisian staf, kepemimpinan, dan pengontrolan untuk optimasi penggunaan sumber-sumber dan pelaksanaan tugastugas dalam mencapai tujuan organisasi secara efektif dan efisien". Manajemen adalah Suatu Proses dalam rangka mencapai tujuan dengan bekerja bersama orang-orang dan sumber daya organisasi lainnya.

Menurut Mary Parker Follet, manajemen sebagai seni menyelesaikan pekerjaan melalui orang lain. Definisi ini berarti bahwa seorang manajer bertugas mengatur dan mengarahkan orang lain untuk mencapai tujuan organisasi.

Menurut Ricky W. Griffin, manajemen adalah sebuah proses perencanaan, pengorganisasian, pengkoordinasian, dan pengontrolan sumber daya untuk mencapai sasaran secara efektif dan efesien. Efektif berarti bahwa tujuan dapat dicapai sesuai 
dengan perencanaan, sementara efisien berarti bahwa tugas yang ada dilaksanakan secara benar, terorganisir, dan sesuai dengan jadwal. ${ }^{1}$

Menurut Prof. Eiji Ogawa, manajemen adalah Perencanaan, Pengimplementasian dan Pengendalian kegiatan-kegiatan termasuk sistem pembuatan barang yang dilakukan oleh organisasi dengan terlebih dahulu telah menetapkan sasaran-sasaran untuk kerja yang dapat disempurnakan sesuai dengan kondisi lingkungan yang berubah.

Dari beberapa definisi menurut asal kata dan definisi dari pendapat ahli, maka dapat ditarik kesimpulan mengenai apa yang dimaksud dengan manajemen. Manajemen adalah Proses perencanaan, pengorganisasian, pelaksanaan dan pengawasan dalam mengelola sumber daya yang berupa man, money, materials, method, machines, market, minute dan information untuk mencapai tujuan yang efektif dan efisien. ${ }^{2}$

Dalam UU Sistem Pendidikan nasional (UU Sisdiknas) Nomer 20 tahun 2003, Pasal 1 ayat $1^{3}$ dikatakan bahwa Pendidikan adalah usaha sadar untuk mewujudkan suasana belajar dan proses pembelajaran agar peserta didik secara aktif mengembangkan potensi dirinya untuk memiliki kekuatan spiritual keagamaan, pengendalian diri, kepribadian, kecerdasan, akhlak mulia, serta keterampilan yang diperlukan dirinya, masyarakat, bangsa dan negara.

Pengertian pendidikan menurut John Dewey, Education is all one with growing; it has no end beyond itself. (Pendidikan adalah segala sesuatu bersamaan dengan pertumbuhan; pendidikan sendiri tidak punya tujuan akhir dibalik dirinya).

${ }^{1}$ Made Pidarta,1988.Manajemen Pendidikan Indonesia, (Jakarta: Bina Aksara), 193

2 Arti Manajemen. (online) http://ielmy.wordpress.com/other/definisimanajemen/. Diakses pada tanggal 17 Agustus 2019

${ }^{3}$ UU Sisdiknas Pasal 1 ayat 1 
Menurut M.J. Langeveld, Pendidikan merupakan upaya manusia dewasa membimbing manusia yang belum dewasa kepada kedewasaan. Pendidikan ialah usaha menolong anak untuk melaksanakan tugas-tugas hidupnya, agar bisa mandiri, akil-baliq, dan bertanggung jawab secara susila. Pendidikan adalah usaha mencapai penentuan, diri, susila dan tanggung jawab.

Pengertian pendidikan menurut Driyarkara, pendidikan didefinisikan sebagai upaya memanusiakan manusia muda atau pengangkatan manusia muda ke taraf insani.

Pengertian pendidikan menurut Stella van Petten Henderson, pendidikan merupakan kombinasai dari pertumbuhan dan perkembangan insani dengan warisan sosial. Pendidikan adalah pembentukan hati nurani. Pendidikan adalah proses pembentukan diri dan penetuan-diri secara etis, sesuai denga hati nurani.

Pengertian pendidikan menurut $\mathrm{H}$. Horne, dalam pengertian luas, pendidikan merupakan perangkat kelompok sosial melanjutkan keberadaannya memperbaharui diri sendiri, dan mempertahankan ideal-idealnya. Carter V. Good pendidikan adalah proses perkembangan kecakapan seseorang dalam bentuk sikap dan perilaku yang berlaku dalam masyarakatnya. Proses sosial dimana seseorang dipengaruhi oleh suatu lingkungan yang terpimpin (khususnya di sekolah) sehingga dapat mencapai kecakapan sosial dan mengembangkan kepribadiannya.

Pengertian pendidikan menurut Thedore Brameld, Istilah pendidikan mengandung fungsi yang luas dari pemelihara dan perbaikan kehidupan suatu masyarakat, terutama membawa warga masyarakat yang baru mengenal tanggung jawab bersama di dalam masyarakat. Jadi pendidikan adalah suatu proses yang lebih luas daripada proses yang berlangsung di dalam sekolah saja. Pendidikan adalah suatu aktivitas sosial yang memungkinkan masyarakat tetap ada dan berkembang. Di dalam masyarakat yang kompleks, fungsi pendidikan ini mengalami spesialisasi dan 
melembaga dengan pendidikan formal yang senantiasa tetap berhubungan dengan proses pendidikan informal di luar sekolah). ${ }^{4}$

Tujuan Pendidikan menurut langeveld, Pendewasaan diri, dengan ciri-cirinya yaitu: kematangan berpikir, kematangan emosional, memiliki harga diri, sikap dan tingkah laku yang dapat diteladani serta kemampuan pengevaluasi diri. Kecakapan atau sikap mandiri, yaitu dapat ditandai pada sedikitnya ketergantungan pada orang lain.

Tujuan pendidikan adalah menciptakan seseorang yang berkualitas dan berkarakter sehingga memiliki pandangan yang luas kedepan untuk mencapai suatu cita-cita yang diharapkan dan mampu beradaptasi secara cepat dan tepat di dalam berbagai lingkungan. Karena pendidikan itu sendiri memotivasi diri kita untuk lebih baik dalam segala aspek kehidupan. ${ }^{5}$

Tujuan Pendidikan dalam (UU Sisdiknas Pasal 3) menyatakan bahwa Pendidikan nasional bertujuan untuk mengembangkan kemampuan dan membentuk watak serta peradaban bangsa yang bermartabat dalam rangka mencerdaskan kehidupan bangsa, bertujuan untuk berkembangnya potensi peserta didik agar menjadi manusia yang beriman dan bertakwa kepada Tuhan Yang Maha Esa, berakhlak mulia, sehat, berilmu, cakap, kreatif, mandiri, dan menjadi warga negara yang demokratis serta bertanggung jawab. ${ }^{6}$

Dilihat dari pengertian manajemen dan pengertian pendidikan diatas, maka kita dapat mendefinisikan Manajemen Pendidikan sebagai suatu Proses perencanaan, pengorganisasian, pelaksanaan dan pengawasan dalam mengelola sumber daya yang berupa man, money, materials, method, machines, market, minute dan

\footnotetext{
${ }^{4}$ Brantas, Dasar-Dasar Manajemen. Jakarta: Alfabeta. 2009.

${ }^{5}$ Siswanto, Pengantar Pendidikan. Jakarta: Bumi Aksara. 2011

${ }^{6}$ UU Sisdiknas Pasal 3.
} 
information untuk mencapai tujuan yang efektif dan efisien dalam bidang pendidikan.

\section{A. Peran dan Fungsi Manajeman Pendidikan}

1) Efisien dalam menggunakan sumber daya.

Dengan mempelajari manajemen pendidikan dengan baik, diharapkan seseorang dapat mengelola sumber daya secara efisien, misalnya sumber daya yang berupa pembiayaan, waktu dan lain sebagainya.

2) Efektif dalam pencapaian tujuan.

Dengan mempelajari manajemen pendidikan secara berkesinambungan dan secara sungguh-sungguh, diharapkan seseorang dapat mengefektifkan proses dan sumber daya yang dikelola untuk mencapai tujuan dengan optimal.

3) Bermuara pada tujuan pendidikan.

Tujuan manajemen pendidikan tidak akan lepas dari tujuan pendidikan nasional, yaitu bertujuan untuk mengembangkan kemampuan dan membentuk watak serta peradaban bangsa yang bermartabat dalam rangka mencerdaskan kehidupan bangsa, bertujuan untuk berkembangnya potensi peserta didik agar menjadi manusia yang beriman dan bertakwa kepada Tuhan Yang Maha Esa, berakhlak mulia, sehat, berilmu, cakap, kreatif, mandiri, dan menjadi warga negara yang demokratis serta bertanggung jawab. ${ }^{7}$

4) Mendukung kegiatan pendidikan dalam upaya mencapai tujuan pendidikan.

Manajemen pendidikan juga mendukung dan memfasilitasi kegiatan pendidikan baik secara langsung maupun tidak langsung. Kegiatan pendidikan yang didukung dengan manajemen pendidikan yang baik, akan mendapatkan hasil yang baik. Fungsi manajemen pendidikan adalah elemen-elemen dasar yang akan

${ }^{7}$ Wahjosumidjo,1999.Kepemimpinan Kepala Sekolah, (Jakarta: Remaja Grafindo Persada), 331 
selalu ada dan melekat di dalam proses manajemen yang akan dijadikan acuan oleh manajer dalam melaksanakan kegiatan pendidikan untuk mencapai tujuan yang efektif dan efisien. Dalam Manajemen terdapat fungsi-fungsi manajemen yang terkait erat di dalamnya.

Menurut George R. Terry, fungsi manajemen ada empat, sekaligus ini menjadi empat fungsi umum manajamen yang banyak dikenal, yaitu fungsi perencanaan (planning), fungsi pengorganisasian (organizing), fungsi pelaksanaan (actuating) dan fungsi pengendalian (controlling).

Menurut Luther Gullick, fungsi manajemen ada tujuh yaitu fungsi perencanaan (planning), fungsi pengorganisasian (organizing), fungsi pengaturan anggota (staffing), fungsi pengarahan (directing), fungsi koordinasi (coordinating), fungsi pelaporan (reporting) dan fungsi pencapaian tujuan (budgeting).

Menurut Hersey and Blanchard, fungsi manajemen ada empat yaitu fungsi perencanaan (planning), fungsi pengorganisasian (organizing), fungsi peningkatan semangat (motivating) dan fungsi pengendalian (controlling).

Pada umumnya ada empat fungsi manajemen yang banyak dikenal masyarakat yaitu fungsi perencanaan (planning), fungsi pengorganisasian (organizing), fungsi pelaksanaan (actuating) dan fungsi pengendalian (controlling). Untuk fungsi pengorganisasian terdapat pula fungsi staffing (pembentukan staf). Para manajer diharapkan mampu menguasai semua fungsi manajemen yang ada untuk mendapatkan hasil manajemen yang maksimal.

Perencanaan (planning) adalah memikirkan apa yang akan dikerjakan dengan sumber yang dimiliki. Perencanaan dilakukan untuk menentukan tujuan perusahaan secara keseluruhan dan cara terbaik untuk memenuhi tujuan itu. Perencanaan juga dapat didefinisikan sebagai proses penyusunan tujuan dan sasaran 
organisasi serta penyusunan "peta kerja" yang memperlihatkan cara pencapaian tujuan dan sasaran tersebut. ${ }^{8}$

Pengorganisasian (organizing) dilakukan dengan tujuan membagi suatu kegiatan besar menjadi kegiatan-kegiatan yang lebih kecil. Pengorganisasian mempermudah manajer dalam melakukan pengawasan dan menentukan orang yang dibutuhkan untuk melaksanakan tugas yang telah dibagi-bagi. Pengorganisasian adalah proses penghimpunan SDM (Sumber Daya Manusia), modal dan peralatan, dengan cara yang paling efektif serta memadukan berbagai sumber daya untuk mencapai tujuan.

Pelaksanaan (actuating) adalah suatu tindakan untuk mengusahakan agar semua anggota kelompok berusaha untuk mencapai sasaran sesuai dengan perencanaan manajerial dan usaha. Pelaksanaan adalah proses penggerakan orang-orang untuk melakukan kegiatan pencapaian tujuan sehingga terwujud efisiensi proses dan efektivitas hasil kerja.

Pengendalian (controlling) adalah suatu aktivitas menilai kinerja berdasarkan standar yang telah dibuat untuk kemudian dibuat perubahan atau perbaikan jika diperlukan. Proses yang dilakukan untuk memastikan seluruh rangkaian kegiatan yang telah direncanakan, diorganisasikan dan diimplementasikan dapat berjalan sesuai dengan target yang dihadapi. Pengendalian dapat didefinisikan sebagai proses pemberian balikan dan tindak lanjut pembandingan antara hasil yang dicapai dengan rencana yang telah ditetapkan dan tindakan penyesuaian apabila terdapat penyimpangan, agar yang ditargetkan dapat tercapai.

${ }^{8}$ Suryosubroto. 2004. Manajemen Pendidikan Di Sekolah. Jakarta: PT Rineka Cipta.45 


\section{B. Ruang Lingkup Manajemen Pendidikan}

Ruang lingkup dari manajemen pendidikan dibagi menjadi tiga kelompok, yaitu : Menurut Wilayah Kerja, Menurut Objek garapan, dan Menurut Fungsi Kegiatan.

Menurut Wilayah kerja, ruang lingkupnya meliputi: Manajemen seluruh negara, manajemen satu propinsi, manajemen satu unit kerja, dan manajemen kelas.

Menurut Objek garapan, ruang lingkupnya meliputi: Manajemen siswa, manajemen ketenaga pendidikan, manajemen sarana-prasarana, manajemen tatalaksana pendidikan, manajemen pembiayaan dan manajemen hubungan masyarakat (humas).

Menurut Fungsi Kegiatan, ruang lingkupnya meliputi: Merencanakan, mengorganisasikan, mengarahkan, mengkoordinasikan, mengkomunikasikan, mengawasi atau mengevaluasi. ${ }^{9}$

${ }^{9}$ Bacal, Robert. 2001. Performance Management. Terj.Surya Darma dan Yanuar Irawan. Jakarta : PT Gramedia Pustaka Utama. 